ISSN 1392-3196 / e-ISSN 2335-8947

Zemdirbyste-Agriculture, vol. 101, No. 4 (2014), p. 453-460

DOI $10.13080 / \mathrm{z}-\mathrm{a} .2014 .101 .058$

\title{
Comparative proteomic analysis of pollen of Trifolium pratense, T. alexandrinum and T. repens
}

\author{
Gražina TREIGYTE் ${ }^{1}$, Ilona ZAIKOVA ${ }^{1}$, Dalius MATUZEVIČIUS ${ }^{2}$, Violeta ČEKSTERYTE் ${ }^{3}$, \\ Giedrè DABKEVIČIENE ${ }^{3}$, Bogumila KURTINAITIENE ${ }^{1}$, Rūta NAVAKAUSKIENE ${ }^{1}$ \\ ${ }^{1}$ Institute of Biochemistry, Vilnius University \\ Mokslininku 12, Vilnius, Lithuania \\ E-mail: ruta.navakauskiene@bchi.vu.lt \\ ${ }^{2}$ Vilnius Gediminas Technical University \\ Naugarduko 41-422, Vilnius, Lithuania \\ ${ }^{3}$ Institute of Agriculture, Lithuanian Research Centre for Agriculture and Forestry \\ Instituto 1, Akademija, Kèdainiai distr., Lithuania
}

\begin{abstract}
Clovers are widely distributed, but their pollen proteome still has not been completely elucidated. In this study we performed a comprehensive comparative proteomic analysis of red, berseem and white clover pollen. Handcollected pollen of different clover species were used for total protein extraction. Proteins isolated from red clover cvs. 'Kiršiniai' and 'Vyčiai', berseem clover cv. 'Faraon' and white clover cv. 'Medūnai', populations Nos. 2295 $4 \mathrm{n}$ and $21964 \mathrm{n}$, were subjected to fractionation by one-dimensional electrophoresis. Some quantitatively different protein groups were characterized in protein maps typical of analyzed clover pollens. For the detailed proteomic analysis we chose pollen of red clover cv. 'Vyčiai', berseem clover cv. 'Faraon' and white clover cv. 'Medūnai'. Proteins isolated from the pollen were fractionated by two-dimensional electrophoresis (2DE) and stained for visualisation by using Coomassie blue. Each of the 2DE images indicated over 200 protein spots. Computational methods developed by us were applied for characterization and comparison of proteins isolated from the pollen of the three clover species. The computational methods enabled the evaluation of protein expression variations in red, berseem and white clover pollen proteome maps. By using computer-assisted image analysis of the gels, the expression levels of the proteins were evaluated and their molecular weight and isoelectric point were precisely characterized. We detected over 30 protein spots whose quantitative levels were most divergent in investigated clover pollen proteome map. They were analyzed by mass spectrometry and identified. The fold changes of identified proteins representing red clover cv. 'Vyčiai', berseem clover cv. 'Faraon' and white clover cv. 'Medūnai' were calculated using computer-assisted methods.
\end{abstract}

Key words: berseem clover, pollen, proteomic analysis, red clover, white clover.

\section{Introduction}

The pollen proteome characteristic of different plant species may vary significantly. The proteomic specificity of pollen can influence the preference of the honeybee and the quality of honey. Therefore it is important to perform a comprehensive analysis of proteomes characteristic of pollen specific to different clover species.

Clovers, like most legumes, are co-evolved complexes of plant, symbiotic bacteria, fungi, and insect pollinators (Vilčinskas, Dabkevičienè, 2009; Williams, Nichols, 2011). The clover genus Trifolium has over 200 species (Ellison et al., 2006; Badr et al., 2008 ), about $10 \%$ of which are used as forage plants in commercial agriculture, and a greater number are used locally for fodder (Williams, Nichols, 2011). The most important clover species are white clover (Trifolium repens L.), red clover (Trifolium pratense L.) and berseem clover (Trifolium alexandrinum L.). Berseem clover is widely cultivated as a forage crop in Asia and Africa. The varieties of genetic improvements of the crop that had been developed in Egypt were later distributed worldwide (Badr et al., 2008). White clover (T. repens L.) is a temperate perennial forage legume widely used in pastoral systems. White clover progenitors are putatively identified as the diploid species. The white clover genome is moderately compact (Griffiths et al., 2013). Proteomic analysis of senescence, a final step of leaf development, was carried out in white clover T. repens. Wilson and co-workers (2002) performed a quantitative analysis of 590 leaf protein spots separated by two-dimensional electrophoresis and indicated that approximately $40 \%$ of the spots (178 spots) showed significant senescence related changes in abundance. Red clover is a species, native to Europe, but planted in many other regions. It is considered that red clover is one of the richest sources of isoflavones. It was found that honey bees could 
be excellent foragers in red clover fields, foraging an average of $98.4 \%$ of the time during peak bloom on the target crop (Jevtic et al., 2013).

In our study we presented a comprehensive proteomic analysis of pollen of three most important clover species - red clover (Trifolium pratense L.), berseem clover (Trifolium alexandrinum L.) and white clover (Trifolium repens L.).

\section{Materials and methods}

Clover species: red clover cvs. 'Kiršiniai' and 'Vyčiai', berseem clover cv. 'Faraon' and white clover cv. 'Medūnai', and populations No. 2295 4n and No. $21964 \mathrm{n}$ were used for pollen production. The clover species were grown in the greenhouse of the Laboratory of Genetics and Physiology, Institute of Agriculture, Lithuanian Research Centre for Agriculture and Forestry in 2013 under controlled conditions (at 18$24^{\circ} \mathrm{C}$ temperature, $16 \mathrm{~h}$ photoperiod). The plants started flowering in April.

Collection of pollen. For pollen collection, flowers were picked from red clover cvs. 'Kiršiniai' and 'Vyčiai', berseem clover cv. 'Faraon' and white clover cv. 'Medūnai', and populations No. 2295 4n and No. 2196 $4 \mathrm{n}$. Pollen grains were manually collected into Eppendorf tubes (Eppendorf AG, Germany) and immediately placed in a storage at $-80^{\circ} \mathrm{C}$ until analysis.

Protein isolation from pollen. Proteins from mature pollen (aprox. $20 \mathrm{mg}$ ) were isolated as described by Sheoran and co-workers (2009). Shortly, mature pollen was homogenized with acetone containing $10 \%$ trichloroacetic acid (TCA) and 1\% dithiothreitol (DTT). The solution was centrifuged $20.000 \times \mathrm{g}$ for $20 \mathrm{~min}$ at $4^{\circ} \mathrm{C}$ and pellet was washed two more times with acetone solution containing 1\% DTT. The pellet was dried in vacuum and proteins were extracted with isoelectric focusing (IEF) lysis buffer containing $9 \mathrm{M}$ urea, $2 \mathrm{M}$ thiourea, 4\% CHAPS (3-[(3-Cholamidopropyl) dimethylammonio]-1- propanesulfonate), $1 \%$ DTT, $0.8 \%$ IPG (immobiline $\mathrm{pH}$ gradient) buffer, $\mathrm{pH} 3-10$. The solution was centrifuged $20.000 \times \mathrm{g}$ for $20 \mathrm{~min}$ at $4^{\circ} \mathrm{C}$ and pellet was extracted again with IEF lysis buffer. After centrifugation, both extracts were combined and directly used for protein analysis or stored at $-20^{\circ} \mathrm{C}$ until analysis.

Gel electrophoresis. The pollen proteins were resolved by sodium dodecyl sulphate-polyacrylamide gel electrophoresis (SDS/PAGE) and two-dimensional gel electrophoresis (IEF/SDS). For the former technique, we used $8-16 \%$ polyacrylamide gradient gel (ICN Biomedicals Inc., Sweden) in tris-glycine electrophoresis buffer. For two-dimensional electrophoresis (2DE) an Immobiline DryStripkit,pHrange 3-10 and Excelgel SDS, gradient $8-18 \%$ was used. It was carried out according to the manufacturer's instructions (Immobiline DryStrip kit for 2DE with Immobiline DryStrip and Excel gel SDS, Pharmacia Biotech, Sweden). For protein visualization gels were stained with colloidal Coomassie G-250 (BioRad Laboratories, USA). For 2DE fractionation of pollen proteins three independent biological experiments were carried out. Images of representative 2DE fractionation are shown in Figures 1 and 2.

In-gel digestion and MALDI-TOF MS. Areas of interest were cut out from the 2DE gels and subjected to overnight in-gel tryptic digestion (Shevchenko et al., 1996). Briefly, the gel slices were dehydrated with $50 \%$ acetonitrile and then dried completely using a centrifugal evaporator DNA Mini (Eppendorf AG). The protein spot was rehydrated in $30 \mu \mathrm{l}$ of $25 \mathrm{mM}$ ammonium bicarbonate ( $\mathrm{pH} 8.3$ ) containing $25 \mu \mathrm{g} \mathrm{ml}^{-1}$ modified trypsin (Promega, USA), and the samples were incubated overnight at $37^{\circ} \mathrm{C}$. The tryptic peptides were subsequently extracted from the gel slices as follows. Any extraneous solution remaining after the digestion was removed and placed in a fresh tube. The gel slices were washed twice with 5\% trifluoracetic acid in $50 \%$ acetonitrile, shaking occasionally. The digestion and extract solutions were then combined and evaporated to dryness. For MALDI-TOF analysis, the peptides were dissolved in $3 \mu \mathrm{l}$ of $30 \%$ acetonitrile and $0.01 \%$ trifluoracetic acid and were then prepared with a matrix ( $\alpha$-cyano-4-hydroxicinnamic acid) on the target plate. The analysis was performed on a 4800 MALDI TOF/TOF ${ }^{\mathrm{TM}}$ mass spectrometer (Applied Biosystems/ MDS SCIEX, Canada) and externally calibrated using synthetic peptides with known masses. MS reflector mode settings: $\mathrm{m} / \mathrm{z}$ range $800-4000$, mass accuracy \pm 50 ppm, MS/MS mode settings: collision energy $1 \mathrm{keV}$, CID - no CID used, fragment mass accuracy $\pm 0.1 \mathrm{Da}$. The mass information generated from the composite spectrum was submitted to a search performed with the databases UniProt and Expasy. Results from three independent biological experiments are summarized in Table.

Image acquisition and data analysis. Stained 2DE gels were digitized on ImageScanner ${ }^{\mathrm{TM}}$ III scanner (GE Healthcare Biosciences, Germany) using software LabScan 6.0 application that is specialized for acquisition of 2DE gel images. To ensure linearity of response and minimize software-induced variance in gel image analysis, calibration of the scanner is performed before scans using provided step tablet. Gels were scanned at 300 dpi resolution and saved in tiff. format. Analysis of 2DE gel images was performed using originally developed software prototype with new pre-processing, alignment, segmentation and subsequent analysis algorithms. All required tools were implemented using programming language Matlab ${ }^{\mathrm{TM}}$ (The MathWorks, USA). Employed software tools allow: to crop gel images in order to keep only protein separation area; align images; automatically detect protein spots; manually edit protein spot area to eliminate false positives and false negatives if needed; quantify spots and estimate expression changes; visualize gel regions in 3-D or 2-D. The process of 2DE gel image analysis can be performed in two basic ways: spot detection and delineation are performed prior to image alignment, or in the reversed order (Dowsey et al., 2010). Gel image analysis workflow used here is as follows: image pre-processing, image alignment, spot detectionsegmentation in aligned images, and differential analysis. A more detailed explanation of the developed and applied algorithms is presented in the Discussion part. 


\section{Results and discussion}

Quantitative analysis of the proteins corresponding to different species of red, berseem and white clover pollen. Pollen proteins were isolated from different clover species: red clover cvs. 'Kiršiniai' and 'Vyčiai', berseem clover cv. 'Faraon', white clover cv. 'Medūnai', populations Nos. 2295 4n and 2196 4n. Electrophoretic analysis of isolated proteins is presented in Figure 1. We determined some proteins groups those quantitative changes are most significant. These protein groups are detected in white clover cv. 'Medūnai' pollen $(\sim 20 \mathrm{kDa})$ and berseem clover cv. 'Faraon' pollen $(\sim 200$, $105,50,15$ and $13 \mathrm{kDa})$.

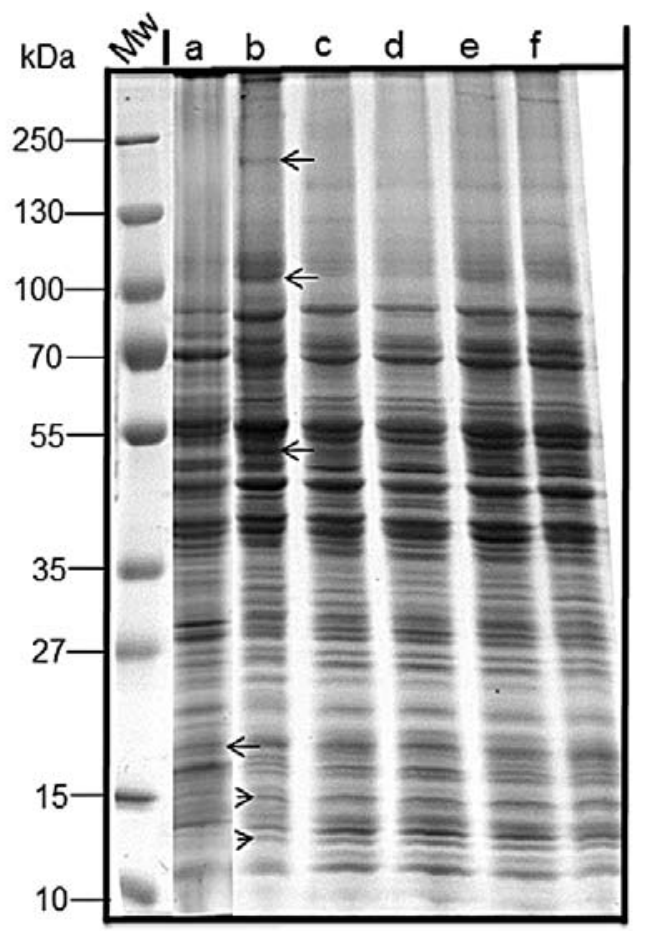

Notes. Proteins from different clover species were isolated as described in the section Materials and methods and fractionated in $8-16 \%$ polyacrylamide gradient gel in trisglycine electrophoresis buffer and visualised by staining with colloidal Coomassie G-250. On the top of SDS/PAGE image clover species is indicated: a) white clover cv. 'Medūnai'; b) berseem clover cv. 'Faraon', c) red clover cv. 'Kiršiniai', d) red clover No. 2295 4n, e) red clover No. 2196 4n; f) red clover cv. 'Vyčiai'. Arrows indicate the protein groups whose quantitative changes are most significant. On the left side of the image the molecular weight is indicated. Representative images from one of three experiments showing similar results are shown.

Figure 1. Gel electrophoretic analysis of clover pollen proteins

2DE gel image analysis for differentially expressed proteins. Gel image analysis workflow used here is as follows: image pre-processing, image alignment, spot detection-segmentation in aligned images, and differential analysis. During the image preprocessing procedure, image cropping, noise reduction, and removal of background variations are carried out. The cropping of the gel images is used to exclude gel edges that are not useful for the image alignment. This improves alignment and reduces computation time.
Noise reduction suppresses randomly occurring white and black pixels (impulse noise). Initial background subtraction is applied in order to compensate interfering variations in the gel background intensity level. Gradual change of background is corrected by the mathematical morphology approach. We used Top-Hat operation subtraction of morphologically opened image from the original image - with disk-shaped structuring element. Gel image alignment and matching of protein spots is needed to enable quantitative comparison of spots from different 2DE gel images (Moller, Posch, 2009). Matching procedure usually requires defining landmarks that are common to both images. Thus the landmarks are the reference points used to guide warping of gel images. We designed image registration algorithm which initially detects strong landmarks between images, uses them for rigid deformation of images, then finds all correspondences between images, and finally computes elastic thin-plate spline transformation for the overlaid visualization of images and for pairing of the protein spots (Bookstein, 1989). During the initial alignment of 2DE gel images, algorithm distinguishes such matches between gel images which have the highest reliability (Matuzevicius, 2010). Initial alignment is based on a few key processes - finding image regions of interest (ROIs), similarity assessment between ROIs, establishment of matches, and error search. Method for detection of similar 2DE image regions is based on multi-layer perceptron combined with Lowe's key point descriptors (Lowe, 2004). Finally, in order to find all spot correspondences between images, similar strategy is used, only the search of similar regions is restricted to the smaller neighbourhoods of the spots. Results of automatic spot pairing, i.e. alignment vectors, may be reviewed and edited manually if correction of mismatches or additional pairings are needed.

Spot detection and segmentation is the next challenging stage in 2DE gel image analysis (Serackis, Navakauskas, 2010). The purpose of protein spot detection is to find probable positions of protein spots. Results of segmentation are spot boundaries that delineate spot area from background and other spots. Segmented spot area is used as ROI for spot volume calculations. Applied protein spot detection and segmentation algorithm is based on watershed transformation (WTS) combined with multiscale symmetrical feature detection. WTS in image analysis is useful for efficient image decomposition into such distinct areas that have only one regional minimum (Vincent, Soille, 1991). Dark protein spots in 2DE gel images are represented as pits of intensity, thus WTS is suitable for image decomposition when spots have to be separated. In order to ensure spot separation, to reduce over segmentation, which is common in image segmentation using WTS due to its sensitivity to image noise, and to enhance spot boundary determination, WTS is performed on feature maps, generated using differences of Gaussians algorithm. Filters designed using differences of Gaussians (DoG) algorithm are key elements in modelling of neural processing in the retina of the eye (Croner, Kaplan, 1995). Similarly to the eye, here DoG algorithm enhances important features of the gel image that guides WTS. Having results of image alignment and segmentation of the protein spots in gel images, a ratio of normalized spot quantities between the image groups can be calculated to estimate changes of spot abundance between the gel groups (Matuzevicius et al., 2008). 
Results of accomplished quantitative 2DE gel (Fig. 2) image analysis are summarized in Table. Ratios of normalized spot quantities together with experimental molecular weight (MW) and isoelectric point (pI) were estimated. Proteins identified by using mass spectrometry analysis are marked with arrows in Figure 2.

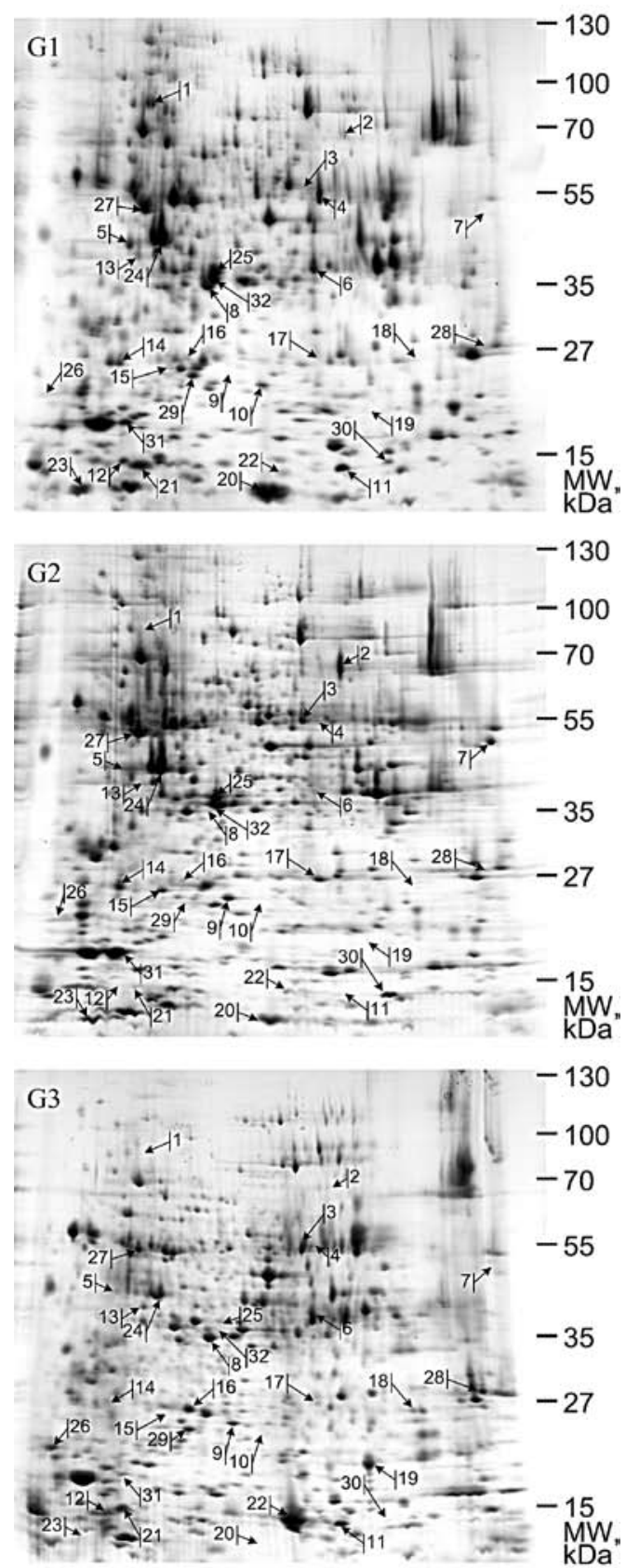

Notes. Proteins isolated from pollen of red clover cv. 'Vyčiai', berseem clover cv. 'Faraon', white clover cv. 'Medūnai' were separated with $2 \mathrm{DE}$ and stained with colloidal Coomassie G-250. For 2DE an Immobiline DryStrip kit, pH range 3-10 and Excel Gel SDS, gradient 8-18\% were used. Protein maps represent total pollen proteins from red clover cv. 'Vyčiai' (G1), berseem clover cv. 'Faraon' (G2) and white clover cv. 'Medūnai' (G3). Arrows and numbers in the 2DE maps indicate the positions of proteins supplied to MALDI-TOF MS/MS and identified. Spot labels are the same as in Table. Representative images from one of the three experiments showing similar results are presented.

Figure 2. 2D gel electrophoretic maps of pollen proteins
Isoelectric points $(\mathrm{pI})$ of identified proteins were calculated by interpolating between known $\mathrm{pI}$ values obtained from the standard pI 3-11 gel. Molecular weights (MWs) of polypeptide spots were computed using a standard procedure, i.e. MWs of proteins were determined by comparing their relative mobility with that of several marker proteins (standards) of a known molecular weight using a standard curve. Molecular weights were determined in all gels from the set before alignment procedure. Changes in spot volume were represented as ratios of averages of normalized spot volumes as described previously. An increase in spot abundance is represented with positive fold change and a decrease, with a negative fold change. Changes between protein spots from gels correspondent with protein maps of red clover cv. 'Vyčiai' (Fig. 2, G1), berseem clover cv. 'Faraon' (Fig. 2, G2) and white clover cv. 'Medūnai' (Fig. 2, G3) are summarized in Table.

Proteomic identification of differentially expressed proteins in clover pollen. For identification and analysis of pollen proteins they were isolated from red clover cv. 'Vyčiai', berseem clover cv. 'Faraon' and white clover cv. 'Medūnai', separated in 2DE system and stained with colloidal Coomassie G-250. Protein spots that were found to be most divergent in quantitative levels in different clover species were cut out and supplied to MALDI-TOF MS/MS analysis and identified. To our knowledge, the proteomic analysis of clover leaves is done by Wilson and co-workers (2002) and it shows that approximately $40 \%$ of identified protein spots are related to senescence changes. Chloroplast protein composition included certain proteins that indicate the importance of proteolysis, chloroplast degradation and remobilisation of nitrogen in leaf senescence (Wilson et al., 2002). Some other proteomic analyses were done on tobacco pollen (Fila et al., 2011), tomato pollen (Sheoran et al., 2007), maize pollen (Zhu et al., 2011) and others.

In the present study we identified more than 30 proteins whose quantitative levels differ in pollen of various clover species. We found that the identified proteins are involved in different cellular processes - structural and signalling proteins, proteins involved in metabolic processes, protein synthesis and folding, etc. We identified structural proteins such as actin, tubulin and profilin. Profilin could act as pollen allergen as well. This function was described by some authors (Noir etal., 2005; Dai et al., 2006; Sheoran et al., 2007). The identified protein uridine diphosphate (UDP)-glucose 6-dehydrogenase is an enzyme that belongs to the family of oxidoreductases and participates in the biosynthesis of glycosaminoglycans. These glycosylated compounds are common components of the extracellular matrix and likely play roles in signal transduction, metabolism and other cellular processes (Kärkönen et al., 2005; Klinghammer, Tenhaken, 2007). Some identified proteins are involved in metabolic processes, i.e. triose phosphate isomerase is involved in several metabolic pathways including glycolysis (Chen, Thelen, 2010), fructokinase is playing role in sucrose and fructose metabolism. Few proteins participating in protein synthesis and folding were identified, i.e. ribosomal proteins, chaperonin CPN60 and others.

In conclusion, we found that the proteins identified in pollen differed in quantity between the three clover species: red clover cv. 'Vyčiai', berseem clover cv. 'Faraon' and white clover cv. 'Medūnai'. This could contribute to the understanding of the protein quantitative change associated with pollen germination of different clover species. 
Table. The summarized search results (by UniProt, Expacy) of proteins identified from 2DE gels representing protein maps of pollen from red clover cv. 'Vyčiai', berseem clover cv. 'Faraon' and white clover cv. 'Medūnai'

\begin{tabular}{|c|c|c|c|c|c|c|c|c|c|c|c|c|c|}
\hline \multirow{3}{*}{ No. ${ }^{1}$} & \multirow{3}{*}{$\mathrm{AC}^{2}$} & \multirow{3}{*}{ Entry } & \multirow{3}{*}{ Description of protein (protein name) } & \multirow{3}{*}{$\begin{array}{c}\mathrm{SC}^{3} \\
\%\end{array}$} & \multirow{3}{*}{$\mathrm{TP}^{4}$} & \multirow[t]{3}{*}{$\mathrm{DP}^{5}$} & \multicolumn{2}{|c|}{ Theoretical } & \multicolumn{2}{|c|}{$\begin{array}{l}\text { Experi- } \\
\text { mental }\end{array}$} & \multicolumn{3}{|c|}{ Fold change } \\
\hline & & & & & & & $\mathrm{Mw}$ & I & Mw & & G1 & G1 & G2 \\
\hline & & & & & & & $\mathrm{kDa}$ & pl & $\mathrm{kDa}$ & pl & G2 & G3 & G3 \\
\hline 1 & 2 & 3 & 4 & 5 & 6 & 7 & 8 & 9 & 10 & 11 & 12 & 13 & 14 \\
\hline $1 a$ & Q9FI17 & ARAE4_ARATH & $\begin{array}{l}\text { Putative UDP-arabinose 4-epimerase } 4 \mathrm{OS}= \\
\text { Arabidopsis thaliana } \mathrm{GN}=\mathrm{At} 5 \mathrm{~g} 44480 \mathrm{PE}=3 \\
\mathrm{SV}=1\end{array}$ & 13 & 56 & 7 & 48.3 & 9.08 & 91 & 5.2 & 3.7 & 10.0 & 2.7 \\
\hline $1 b$ & Q8GT21 & BEBT_CLABR & $\begin{array}{l}\text { Benzyl alcohol O-benzoyltransferase OS }= \\
\text { Clarkia breweri } \mathrm{PE}=1 \mathrm{SV}=1\end{array}$ & 8 & 49 & 4 & 50.6 & 6.29 & & & & & \\
\hline 2 & P35480 & CH60_BRANA & $\begin{array}{l}\text { Chaperonin CPN60, mitochondrial OS }= \\
\text { Brassica napus } \mathrm{PE}=2 \mathrm{SV}=1\end{array}$ & 17 & 78 & 8 & 62.3 & 8.37 & 63 & 7.7 & -4.2 & 2.4 & 10.1 \\
\hline $3 a$ & Q2QS14 & UGDH4_ORYSJ & $\begin{array}{l}\text { UDP-glucose 6-dehydrogenase } 4 \mathrm{OS}=\text { Oryza sativa } \\
\text { subsp. japonica } \mathrm{GN}=\mathrm{UGD} 4 \mathrm{PE}=2 \mathrm{SV}=1\end{array}$ & 26 & 55 & 10 & 52.8 & 5.80 & 56 & 7.2 & -2.3 & -2.1 & 1.1 \\
\hline $3 b$ & Q2QS13 & UGDH5_ORYSJ & $\begin{array}{l}\text { UDP-glucose 6-dehydrogenase } 5 \mathrm{OS}=\text { Oryza sativa } \\
\text { subsp. japonica } \mathrm{GN}=\mathrm{UGD} 5 \mathrm{PE}=2 \mathrm{SV}=1\end{array}$ & 26 & 56 & 10 & 52.9 & 5.79 & & & & & \\
\hline $3 c$ & Q9FZE1 & UGDH1_ARATH & $\begin{array}{l}\text { UDP-glucose 6-dehydrogenase } 1 \mathrm{OS}= \\
\text { Arabidopsis thaliana } \mathrm{GN}=\mathrm{UGD} 1 \mathrm{PE}=2 \mathrm{SV}=1\end{array}$ & 32 & 56 & 10 & 52.9 & 5.84 & & & & & \\
\hline $3 d$ & Q9LIA8 & UGDH2_ARATH & $\begin{array}{l}\text { UDP-glucose 6-dehydrogenase } 2 \mathrm{OS}= \\
\text { Arabidopsis thaliana } \mathrm{GN}=\mathrm{UGD} 2 \mathrm{PE}=1 \mathrm{SV}=1\end{array}$ & 13 & 54 & 7 & 53.1 & 5.69 & & & & & \\
\hline $3 e$ & Q9AUV6 & UGDH3_ORYSJ & $\begin{array}{l}\text { UDP-glucose 6-dehydrogenase } 3 \mathrm{OS}=\text { Oryza sativa } \\
\text { subsp. japonica } \mathrm{GN}=\mathrm{UGD} 3 \mathrm{PE}=2 \mathrm{SV}=1\end{array}$ & 21 & 55 & 9 & 52.9 & 5.79 & & & & & \\
\hline $3 f$ & Q96558 & UGDH1_SOYBN & $\begin{array}{l}\text { UDP-glucose 6-dehydrogenase } 1 \mathrm{OS}=\text { Glycine } \max \\
\mathrm{GN}=\mathrm{UGD} 1 \mathrm{PE}=1 \mathrm{SV}=1\end{array}$ & 14 & 54 & 6 & 52.9 & 5.74 & & & & & \\
\hline $4 a$ & Q2QS13 & UGDH5_ORYSJ & $\begin{array}{l}\text { UDP-glucose 6-dehydrogenase } 5 \mathrm{OS}=\text { Oryza sativa } \\
\text { subsp. japonica } \mathrm{GN}=\mathrm{UGD} 5 \mathrm{PE}=2 \mathrm{SV}=1\end{array}$ & 34 & 56 & 12 & 52.9 & 5.79 & 55 & 7.5 & 1.6 & 1.8 & 1.1 \\
\hline $4 b$ & Q2QS14 & UGDH4_ORYSJ & $\begin{array}{l}\text { UDP-glucose 6-dehydrogenase } 4 \mathrm{OS}=\text { Oryza sativa } \\
\text { subsp. japonica } \mathrm{GN}=\mathrm{UGD} 4 \mathrm{PE}=2 \mathrm{SV}=1\end{array}$ & 30 & 55 & 11 & 52.8 & 5.80 & & & & & \\
\hline $4 c$ & Q9AUV6 & UGDH3_ORYSJ & $\begin{array}{l}\text { UDP-glucose 6-dehydrogenase } 3 \mathrm{OS}=\text { Oryza sativa } \\
\text { subsp. japonica } \mathrm{GN}=\mathrm{UGD} 3 \mathrm{PE}=2 \mathrm{SV}=1\end{array}$ & 28 & 55 & 11 & 52.9 & 5.79 & & & & & \\
\hline $4 d$ & Q9FM01 & UGDH4_ARATH & $\begin{array}{l}\text { UDP-glucose 6-dehydrogenase } 4 \mathrm{OS}= \\
\text { Arabidopsis thaliana } \mathrm{GN}=\mathrm{UGD} 4 \mathrm{PE}=1 \mathrm{SV}=1\end{array}$ & 22 & 52 & 10 & 53.1 & 5.60 & & & & & \\
\hline $4 e$ & Q9LIA8 & UGDH2_ARATH & $\begin{array}{l}\text { UDP-glucose 6-dehydrogenase } 2 \mathrm{OS}= \\
\text { Arabidopsis thaliana } \mathrm{GN}=\mathrm{UGD} 2 \mathrm{PE}=1 \mathrm{SV}=1\end{array}$ & 16 & 54 & 8 & 53.1 & 5.69 & & & & & \\
\hline $4 f$ & Q96558 & UGDH1_SOYBN & $\begin{array}{l}\text { UDP-glucose 6-dehydrogenase } 1 \mathrm{OS}=\text { Glycine max } \\
\mathrm{GN}=\mathrm{UGD} 1 \mathrm{PE}=1 \mathrm{SV}=1\end{array}$ & 17 & 54 & 7 & 52.9 & 5.74 & & & & & \\
\hline 5 & P30171 & ACT11_SOLTU & $\begin{array}{l}\text { Actin- } 97 \mathrm{OS}=\text { Solanum tuberosum } \mathrm{GN}=\mathrm{AC} 97 \\
\mathrm{PE}=1 \mathrm{SV}=1\end{array}$ & 38 & 39 & 12 & 41.6 & 5.31 & 45 & 5.1 & 1.4 & 2.0 & 1.5 \\
\hline $6 a$ & Q0J6T3 & CADH5_ORYSJ & $\begin{array}{l}\text { Putative cinnamyl alcohol dehydrogenase } 5 \mathrm{OS}= \\
\text { Oryza sativa subsp. japonica } \mathrm{GN}=\mathrm{CAD} 5 \mathrm{PE}=3 \\
\mathrm{SV}=2\end{array}$ & 7 & 33 & 3 & 37.2 & 6.41 & 40 & 6.5 & 1.9 & -1.2 & -2.2 \\
\hline $6 b$ & Q9ZRF1 & MTDH_FRAAN & $\begin{array}{l}\text { Probable mannitol dehydrogenase } \mathrm{OS}= \\
\text { Fragaria ananassa } \mathrm{GN}=\mathrm{CAD} \mathrm{PE}=1 \mathrm{SV}=1\end{array}$ & 24 & 39 & 5 & 39.1 & 6.46 & & & & & \\
\hline $6 c$ & Q6V4H0 & 10HGO_CATRO & $\begin{array}{l}\text { 8-hydroxygeraniol dehydrogenase } \mathrm{OS}= \\
\text { Catharanthus roseus } \mathrm{GN}=10 \mathrm{HGO} \mathrm{PE}=1 \mathrm{SV}=1\end{array}$ & 21 & 39 & 6 & 38.9 & 6.67 & & & & & \\
\hline 7 & P37706 & RRFC_DAUCA & $\begin{array}{l}\text { Ribosome-recycling factor, chloroplastic (fragment) } \\
\mathrm{OS}=\text { Daucus carota } \mathrm{GN}=\mathrm{RRF} \mathrm{PE}=2 \mathrm{SV}=2\end{array}$ & 28 & 44 & 9 & 25.6 & 9.36 & 47 & 10.2 & -12.9 & -1.6 & 8.0 \\
\hline $8 a$ & A2WXV8 & SCRK1_ORYSI & $\begin{array}{l}\text { Fructokinase- } 1 \mathrm{OS}=\text { Oryza sativa } \text { subsp. indica } \\
\mathrm{GN}=\mathrm{FRK} 1 \mathrm{PE}=1 \mathrm{SV}=1\end{array}$ & 21 & 36 & 8 & 34.7 & 5.14 & 34 & 5.4 & 1.6 & 1.4 & -1.1 \\
\hline $8 b$ & Q0JGZ6 & SCRK1_ORYSJ & $\begin{array}{l}\text { Fructokinase- } 1 \mathrm{OS}=\text { Oryza sativa } \text { subsp. japonica } \\
\mathrm{GN}=\mathrm{FRK} 1 \mathrm{PE}=1 \mathrm{SV}=2\end{array}$ & 17 & 36 & 7 & 34.7 & 5.07 & & & & & \\
\hline $8 c$ & Q6XZ79 & SCRK1_MAIZE & $\begin{array}{l}\text { Fructokinase-1 OS }=\text { Zea mays } \mathrm{GN}=\mathrm{FRK} 1 \mathrm{PE}= \\
1 \mathrm{SV}=1\end{array}$ & 21 & 34 & 7 & 34.7 & 4.87 & & & & & \\
\hline $8 d$ & Q9M1B9 & SCRK4_ARATH & $\begin{array}{l}\text { Probable fructokinase- } 4 \mathrm{OS}=\text { Arabidopsis thaliana } \\
\mathrm{GN}=\mathrm{At} 3 \mathrm{~g} 59480 \mathrm{PE}=2 \mathrm{SV}=1\end{array}$ & 18 & 36 & 6 & 35.0 & 5.21 & & & & & \\
\hline $8 e$ & Q6XZ78 & SCRK2_MAIZE & $\begin{array}{l}\text { Fructokinase- } 2 \mathrm{OS}=\text { Zea mays } \mathrm{GN}=\mathrm{FRK} 2 \mathrm{PE}= \\
1 \mathrm{SV}=1\end{array}$ & 13 & 35 & 6 & 35.5 & 5.34 & & & & & \\
\hline $9 a$ & P48497 & TPIS_STELP & $\begin{array}{l}\text { Triosephosphate isomerase, cytosolic } \mathrm{OS}= \\
\text { Stellaria longipes } \mathrm{GN}=\mathrm{TPI} \mathrm{PE}=1 \mathrm{SV}=1\end{array}$ & 14 & 26 & 3 & 27.5 & 5.54 & 26 & 6.9 & -12.3 & -10.1 & 1.2 \\
\hline $9 b$ & P48495 & TPIS_PETHY & $\begin{array}{l}\text { Triosephosphate isomerase, cytosolic } \mathrm{OS}= \\
\text { Petunia hybrida } \mathrm{GN}=\mathrm{TPIP} 1 \mathrm{PE}=2 \mathrm{SV}=1\end{array}$ & 9 & 27 & 3 & 27.1 & 5.54 & & & & & \\
\hline $9 c$ & P46225 & TPIC_SECCE & $\begin{array}{l}\text { Triosephosphate isomerase, chloroplastic } \mathrm{OS}= \\
\text { Secale cereale } \mathrm{PE}=1 \mathrm{SV}=1\end{array}$ & 8 & 32 & 3 & 31.6 & 6.00 & & & & & \\
\hline $9 d$ & P46226 & TPIS_SECCE & $\begin{array}{l}\text { Triosephosphate isomerase, cytosolic } \mathrm{OS}= \\
\text { Secale cereale } \mathrm{PE}=2 \mathrm{SV}=3\end{array}$ & 9 & 24 & 2 & 26.9 & 5.24 & & & & & \\
\hline $9 e$ & P12863 & TPIS_MAIZE & $\begin{array}{l}\text { Triosephosphate isomerase, cytosolic } \mathrm{OS}= \\
\text { Zea mays } \mathrm{PE}=3 \mathrm{SV}=3\end{array}$ & 8 & 25 & 2 & 27.0 & 5.52 & & & & & \\
\hline $10 a$ & O04905 & KCY_ARATH & $\begin{array}{l}\text { UMP-CMP kinase OS }=\text { Arabidopsis thaliana } \\
\mathrm{GN}=\mathrm{PYR} 6 \mathrm{PE}=1 \mathrm{SV}=1\end{array}$ & 14 & 30 & 4 & 22.5 & 5.79 & 21 & 6.9 & 7.9 & 3.3 & -2.4 \\
\hline $10 b$ & $\mathrm{O} 24464$ & KCY_PRUAR & $\begin{array}{l}\text { UMP-CMP kinase OS = Prunus armeniaca } \\
\mathrm{PE}=2 \mathrm{SV}=1\end{array}$ & 3 & 30 & 1 & 25.9 & 7.75 & & & & & \\
\hline $11 a$ & $\mathrm{O} 24464$ & NDK4_SPIOL & $\begin{array}{l}\text { Nucleoside diphosphate kinase } 4, \text { chloroplastic } \\
\mathrm{OS}=\text { Spinacia oleracea } \mathrm{GN}=\mathrm{NDK} 4 \mathrm{PE}=1 \mathrm{SV}=1\end{array}$ & 20 & 31 & 4 & 25.7 & 9.15 & 13 & 8.2 & 7.1 & -1.1 & -7.9 \\
\hline $11 b$ & P81766 & NDK3_SPIOL & $\begin{array}{l}\text { Nucleoside diphosphate kinase } 3 \mathrm{OS}= \\
\text { Spinacia oleracea } \mathrm{PE}=1 \mathrm{SV}=1\end{array}$ & 24 & 22 & 3 & 17.1 & 8.12 & & & & & \\
\hline
\end{tabular}




\section{Table continued}

\begin{tabular}{|c|c|c|c|c|c|c|c|c|c|c|c|c|c|}
\hline 1 & 2 & 3 & 4 & 5 & 6 & 7 & 8 & 9 & 10 & 11 & 12 & 13 & 14 \\
\hline $11 c$ & O49203 & NDK3_ARATH & $\begin{array}{l}\text { Nucleoside diphosphate kinase III, chloroplastic/ } \\
\text { mitochondrial OS = Arabidopsis thaliana } \\
\mathrm{GN}=\text { NDPK } 3 \mathrm{PE}=1 \mathrm{SV}=1\end{array}$ & 12 & 31 & 3 & 25.7 & 9.28 & & & & & \\
\hline $11 d$ & Q8LAH8 & NDK4_ARATH & $\begin{array}{l}\text { Nucleoside diphosphate kinase IV, chloroplastic/ } \\
\text { mitochondrial OS = Arabidopsis thaliana } \\
\mathrm{GN}=\mathrm{NDK} 4 \mathrm{PE}=1 \mathrm{SV}=2\end{array}$ & 12 & 30 & 3 & 25.8 & 9.44 & & & & & \\
\hline $12 a$ & Q7YJV4 & RR18_CALFG & $\begin{array}{l}30 \mathrm{~S} \text { ribosomal protein } \mathrm{S} 18 \text {, chloroplastic } \mathrm{OS}= \\
\text { Calycanthus floridus var. glaucus } \\
\mathrm{GN}=\operatorname{rps} 18 \mathrm{PE}=3 \mathrm{SV}=1\end{array}$ & 46 & 26 & 5 & 11.8 & 11.96 & 13 & 4.2 & 3.0 & -1.4 & -4.1 \\
\hline $12 b$ & Q0G9J7 & RR18_LIRTU & $\begin{array}{l}\text { 30S ribosomal protein } \mathrm{S} 18 \text {, chloroplastic } \mathrm{OS}= \\
\text { Liriodendron tulipifera } \mathrm{GN}=\operatorname{rps} 18 \mathrm{PE}=3 \mathrm{SV}=1\end{array}$ & 19 & 26 & 5 & 11.9 & 11.9 & & & & & \\
\hline 13 & Q84LB6 & SUCB_SOLLC & $\begin{array}{l}\text { Succinyl-CoA ligase [ADP-forming] subunit beta, } \\
\text { mitochondrial } \mathrm{OS}=\text { Solanum lycopersicum } \mathrm{PE}=1 \\
\mathrm{SV}=1\end{array}$ & 28 & 52 & 8 & 44.8 & 5.86 & 38 & 4.2 & 1.6 & 1.0 & -1.6 \\
\hline 14 & P80042 & GGPPS_CAPAN & $\begin{array}{l}\text { Geranylgeranyl pyrophosphate synthase, } \\
\text { chloroplastic } \mathrm{OS}=\text { Capsicum annuum } \\
\mathrm{GN}=\text { GGPS } 1 \mathrm{PE}=3 \mathrm{SV}=1\end{array}$ & 23 & 44 & 6 & 40.1 & 6.12 & 26 & 5.1 & -1.5 & 1.8 & 2.7 \\
\hline 15 & Q6AUR2 & GLNB_ORYSJ & $\begin{array}{l}\text { Nitrogen regulatory protein } \mathrm{P}-\mathrm{II} \text { homolog } \mathrm{OS}= \\
\text { Oryza sativa subsp. japonica } \mathrm{GN}=\mathrm{GLB} \mathrm{PE}=2 \\
\mathrm{SV}=1\end{array}$ & 7 & 30 & 2 & 22.7 & 9.91 & 25 & 5.2 & -1.8 & 3.5 & 6.3 \\
\hline $16 a$ & P21216 & IPYR2_ARATH & $\begin{array}{l}\text { Soluble inorganic pyrophosphatase } 2 \mathrm{OS}= \\
\text { Arabidopsis thaliana } \mathrm{GN}=\mathrm{PPA} 2 \mathrm{PE}=2 \mathrm{SV}=2\end{array}$ & 22 & 29 & 7 & 24.7 & 5.72 & 26 & 5.7 & 1.2 & -2.1 & -2.5 \\
\hline $16 b$ & Q949J1 & IPYR2_CHLRE & $\begin{array}{l}\text { Soluble inorganic pyrophosphatase } 2 \mathrm{OS}= \\
\text { Chlamydomonas reinhardtii } \mathrm{GN}=\text { ppa } 2 \mathrm{PE}=1 \\
\mathrm{SV}=1\end{array}$ & 19 & 25 & 5 & 22.2 & 5.49 & & & & & \\
\hline $16 c$ & Q0DYB1 & IPYR_ORYSJ & $\begin{array}{l}\text { Soluble inorganic pyrophosphatase } \mathrm{OS}=\text { Oryza } \\
\text { sativa } \text { subsp. japonica } \mathrm{GN}=\mathrm{IPP} \mathrm{PE}=2 \mathrm{SV}=1\end{array}$ & 11 & 27 & 5 & 24.1 & 5.56 & & & & & \\
\hline $16 d$ & Q43187 & IPYR_SOLTU & $\begin{array}{l}\text { Soluble inorganic pyrophosphatase } \mathrm{OS}= \\
\text { Solanum tuberosum } \mathrm{GN}=\mathrm{PPA} \mathrm{PE}=2 \mathrm{SV}=1\end{array}$ & 11 & 28 & 5 & 24.2 & 5.59 & & & & & \\
\hline $16 e$ & O48556 & IPYR_MAIZE & $\begin{array}{l}\text { Soluble inorganic pyrophosphatase } \mathrm{OS}=\text { Zea mays } \\
\mathrm{GN}=\mathrm{IPP} \mathrm{PE}=2 \mathrm{SV}=1\end{array}$ & 17 & 29 & 5 & 24.4 & 5.46 & & & & & \\
\hline 17 & P46745 & RT07_PROWI & $\begin{array}{l}\text { Ribosomal protein } \mathrm{S} 7, \text { mitochondrial } \mathrm{OS}= \\
\text { Prototheca } \text { wickerhamii } \mathrm{GN}=\mathrm{RPS} 7 \mathrm{PE}=3 \mathrm{SV}=1\end{array}$ & 9 & 38 & 3 & 25.2 & 9.83 & 26 & 7.6 & -3.2 & -1.1 & 2.9 \\
\hline 18 & Q5N9Q7 & PTHM_ORYSJ & $\begin{array}{l}\text { Peptidyl-tRNA hydrolase, mitochondrial } \mathrm{OS}= \\
\text { Oryza sativa } \text { subsp. } \text { japonica } \mathrm{GN}=\mathrm{Os} 01 \mathrm{~g} 0693900 \\
\mathrm{PE}=2 \mathrm{SV}=1\end{array}$ & 18 & 31 & 5 & 26.9 & 10.01 & 25 & 8.9 & 1.6 & -2.6 & -4.0 \\
\hline 19 & A4GGE1 & YCF2_PHAVU & $\begin{array}{l}\text { Protein ycf } 2 \mathrm{OS}=\text { Phaseolus vulgaris } \\
\mathrm{GN}=\text { ycf } 2-\mathrm{A} \mathrm{PE}=3 \mathrm{SV}=1\end{array}$ & 9 & 282 & 15 & 26.9 & 8.74 & 15 & 8.5 & -4.1 & -11.8 & -2.9 \\
\hline 20 & Q9TJQ9 & RR7_PROWI & $\begin{array}{l}\text { 30S ribosomal protein } \mathrm{S} 7, \text { plastid } \mathrm{OS}= \\
\text { Prototheca } \text { wickerhamii } \mathrm{GN}=\operatorname{rps} 7 \mathrm{PE}=3 \mathrm{SV}=1\end{array}$ & 12 & 35 & 2 & 17.9 & 10.51 & 12 & 7.1 & 2.2 & 16.3 & 7.4 \\
\hline 21 & A1XFZ5 & RK22_NUPAD & $\begin{array}{l}\text { 50S ribosomal protein } \mathrm{L} 22, \text { chloroplastic } \mathrm{OS}= \\
\text { Nuphar advena } \mathrm{GN}=\mathrm{rp1} 22 \mathrm{PE}=3 \mathrm{SV}=1\end{array}$ & 52 & 23 & 8 & 14.2 & 10.18 & 13 & 4.9 & 3.3 & 1.3 & -2.6 \\
\hline $22 a$ & P47922 & NDK1_PEA & $\begin{array}{l}\text { Nucleoside diphosphate kinase } 1 \mathrm{OS}= \\
\text { Pisum sativum } \mathrm{GN}=\mathrm{NDPK} 1 \mathrm{PE}=1 \mathrm{SV}=1\end{array}$ & 34 & 17 & 6 & 16.5 & 5.94 & 14 & 7.3 & 1.3 & -7.1 & -9.5 \\
\hline $22 b$ & Q39839 & NDK1_SOYBN & $\begin{array}{l}\text { Nucleoside diphosphate kinase } 1 \mathrm{OS}=\text { Glycine } \max \\
\mathrm{PE}=1 \mathrm{SV}=1\end{array}$ & 26 & 17 & 4 & 16.4 & 5.93 & & & & & \\
\hline $23 a$ & A4GE48 & PROBU_OLEEU & Profilin-2 OS $=$ Olea europaea $\mathrm{PE}=1 \mathrm{SV}=1$ & 28 & 10 & 2 & 14.375 & 5.06 & 13 & 4.5 & 1.1 & 4.0 & 3.5 \\
\hline $23 b$ & O65812 & PROF1_HEVBR & Profilin-1 OS $=$ Hevea brasiliensis $\mathrm{PE}=1 \mathrm{SV}=1$ & 9 & 10 & 1 & 14.2 & 4.66 & & & & & \\
\hline $23 c$ & Q8H2C8 & PROF2_ARTVU & Profilin-2 OS $=$ Artemisia vulgaris $\mathrm{PE}=1 \mathrm{SV}=3$ & 8 & 12 & 1 & 14.3 & 4.79 & & & & & \\
\hline $23 d$ & P0DKE6 & PROAB_OLEEU & Profilin-3 OS $=$ Olea europaea $\mathrm{PE}=1 \mathrm{SV}=1$ & 10 & 10 & 1 & 14.4 & 5.21 & & & & & \\
\hline $24 a$ & P30171 & ACT11_SOLTU & $\begin{array}{l}\text { Actin-97 OS }=\text { Solanum tuberosum } \\
\mathrm{GN}=\mathrm{AC} 97 \mathrm{PE}=1 \mathrm{SV}=1\end{array}$ & 58 & 39 & 20 & 41.6 & 5.31 & 51 & 5.4 & -1.3 & 1.7 & 2.2 \\
\hline $24 b$ & P53496 & ACT11_ARATH & $\begin{array}{l}\text { Actin-11 OS }=\text { Arabidopsis thaliana } \\
\mathrm{GN}=\mathrm{ACT} 11 \mathrm{PE}=1 \mathrm{SV}=1\end{array}$ & 53 & 38 & 19 & 41.6 & 5.23 & & & & & \\
\hline $24 c$ & O81221 & ACT_GOSHI & Actin $\mathrm{OS}=$ Gossypium hirsutum $\mathrm{PE}=3 \mathrm{SV}=1$ & 59 & 39 & 21 & 41.6 & 5.31 & & & & & \\
\hline $24 d$ & Q05214 & ACT1_TOBAC & Actin $\mathrm{OS}=$ Nicotiana tabacum $\mathrm{PE}=3 \mathrm{SV}=1$ & 57 & 40 & 19 & 41.7 & 5.46 & & & & & \\
\hline $24 e$ & P53504 & ACT1_SORBI & $\begin{array}{l}\text { Actin-1 OS }=\text { Sorghum bicolor } \mathrm{GN}=\mathrm{AC} 1 \mathrm{PE}=2 \\
\mathrm{SV}=1\end{array}$ & 55 & 39 & 18 & 41.8 & 5.44 & & & & & \\
\hline $24 f$ & Q10DV7 & ACT1_ORYSJ & $\begin{array}{l}\text { Actin-1 OS }=\text { Oryza sativa subsp. japonica } \\
\mathrm{GN}=\mathrm{ACT} 1 \mathrm{PE}=2 \mathrm{SV}=1\end{array}$ & 60 & 39 & 16 & 41.8 & 5.30 & & & & & \\
\hline $25 a$ & Q8H8T0 & RGP1_ORYSJ & $\begin{array}{l}\text { UDP-arabinopyranose mutase } 1 \mathrm{OS}=\text { Oryza sativa } \\
\text { subsp. japonica } \mathrm{GN}=\mathrm{UAM} 1 \mathrm{PE}=1 \mathrm{SV}=1\end{array}$ & 15 & 41 & 6 & 41.3 & 5.82 & 36 & 6.2 & 1.0 & 4.5 & 4.4 \\
\hline $25 b$ & Q9FFD2 & RGP5_ARATH & $\begin{array}{l}\text { Probable UDP-arabinopyranose mutase } 5 \mathrm{OS}= \\
\text { Arabidopsis thaliana } \mathrm{GN}=\mathrm{RGP} 5 \mathrm{PE}=1 \mathrm{SV}=1\end{array}$ & 15 & 37 & 5 & 38.6 & 5.06 & & & & & \\
\hline $25 c$ & Q9SRT9 & RGP1_ARATH & $\begin{array}{l}\text { UDP-arabinopyranose mutase } 1 \mathrm{OS}= \\
\text { Arabidopsis thaliana } \mathrm{GN}=\mathrm{RGP} 1 \mathrm{PE}=1 \mathrm{SV}=1\end{array}$ & 21 & 39 & 6 & 40.6 & 5.61 & & & & & \\
\hline $25 d$ & Q7FAY6 & RGP2_ORYSJ & $\begin{array}{l}\text { Probable UDP-arabinopyranose mutase } 2 \mathrm{OS}= \\
\text { Oryza sativa subsp. japonica } \mathrm{GN}=\mathrm{UAM} 2 \mathrm{PE}=1 \\
\mathrm{SV}=1\end{array}$ & 19 & 40 & 5 & 38.9 & 6.02 & & & & & \\
\hline $25 e$ & Q9LFW1 & RGP2_ARATH & $\begin{array}{l}\text { UDP-arabinopyranose mutase } 2 \mathrm{OS}= \\
\text { Arabidopsis thaliana } \mathrm{GN}=\mathrm{RGP} 2 \mathrm{PE}=1 \mathrm{SV}=1\end{array}$ & 17 & 40 & 5 & 40.9 & 5.76 & & & & & \\
\hline $25 f$ & P80607 & UPTG_MAIZE & $\begin{array}{l}\text { Alpha-1,4-glucan-protein synthase [UDP-forming] } \\
\mathrm{OS}=\text { Zea mays } \mathrm{GN}=\mathrm{UPTG} \mathrm{PE}=1 \mathrm{SV}=2\end{array}$ & 12 & 39 & 4 & 41.2 & 5.75 & & & & & \\
\hline $25 g$ & O04300 & UPTG_PEA & $\begin{array}{l}\text { Alpha-1,4-glucan-protein synthase [UDP-forming] } \\
\mathrm{OS}=\text { Pisum sativum } \mathrm{GN}=\mathrm{UPTG} \mathrm{PE}=1 \mathrm{SV}=1\end{array}$ & 12 & 40 & 4 & 41.5 & 5.73 & & & & & \\
\hline
\end{tabular}


Table continued

\begin{tabular}{|c|c|c|c|c|c|c|c|c|c|c|c|c|c|}
\hline 1 & 2 & 3 & 4 & 5 & 6 & 7 & 8 & 9 & 10 & 11 & 12 & 13 & 14 \\
\hline 26 & Q9ZVF2 & ML329_ARATH & MLP-like protein 329 OS = Arabidopsis thaliana & 50 & 20 & 7 & 17.6 & 5.30 & 23 & 4.2 & -1.3 & -2.6 & -2.0 \\
\hline $27 a$ & P33629 & TBA_PRUDU & $\begin{array}{l}\mathrm{GN}=\mathrm{MLP} 329 \mathrm{PE}=2 \mathrm{SV}=1 \\
\text { Tubulin alpha chain } \mathrm{OS}=\text { Prunus dulcis } \\
\mathrm{GN}=\mathrm{TUBA} \mathrm{PE}=2 \mathrm{SV}=1\end{array}$ & 44 & 41 & 14 & 49.5 & 4.92 & 50 & 5.1 & -1.3 & 1.5 & 1.9 \\
\hline $27 b$ & P46259 & TBA1_PEA & $\begin{array}{l}\text { Tubulin alpha- } 1 \text { chain } \mathrm{OS}=\text { Pisum sativum } \\
\mathrm{GN}=\text { TUBA } 1 \mathrm{PE}=1 \mathrm{SV}=1\end{array}$ & 44 & 41 & 14 & 49.6 & 4.92 & & & & & \\
\hline $27 c$ & Q6VAG0 & TBA2_GOSHI & $\begin{array}{l}\text { Tubulin alpha- } 2 \text { chain } \mathrm{OS}=\text { Gossypium hirsutum } \\
\mathrm{PE}=2 \mathrm{SV}=1\end{array}$ & 39 & 41 & 13 & 49.5 & 4.93 & & & & & \\
\hline $27 d$ & Q6VAF9 & TBA4_GOSHI & $\begin{array}{l}\text { Tubulin alpha- } 4 \text { chain } \mathrm{OS}=\text { Gossypium hirsutum } \\
\mathrm{PE}=2 \mathrm{SV}=1\end{array}$ & 42 & 41 & 13 & 49.5 & 4.93 & & & & & \\
\hline $27 e$ & Q9ZRB7 & TBA_WHEAT & $\begin{array}{l}\text { Tubulin alpha chain } \mathrm{OS}=\text { Triticum aestivum } \\
\mathrm{GN}=\mathrm{TUBA} \mathrm{PE}=2 \mathrm{SV}=1\end{array}$ & & 41 & 12 & 49.7 & 4.89 & & & & & \\
\hline $27 f$ & Q9ZRR5 & TBA3_HORVU & $\begin{array}{l}\text { Tubulin alpha- } 3 \text { chain } \mathrm{OS}=\text { Hordeum vulgare } \\
\mathrm{GN}=\mathrm{TUBA} 3 \mathrm{PE}=2 \mathrm{SV}=1\end{array}$ & 27 & 41 & 8 & 49.7 & 4.89 & & & & & \\
\hline $27 g$ & P14640 & TBA1_MAIZE & $\begin{array}{l}\text { Tubulin alpha- } 1 \text { chain } \mathrm{OS}=\text { Zea mays } \\
\mathrm{GN}=\mathrm{TUBA} 1 \mathrm{PE}=3 \mathrm{SV}=1\end{array}$ & 17 & 41 & 7 & 49.7 & 4.89 & & & & & \\
\hline $28 a$ & P42054 & VDAC_PEA & $\begin{array}{l}\text { Outer plastidial membrane protein porin } \mathrm{OS}= \\
\text { Pisum sativum } \mathrm{GN}=\mathrm{POR} 1 \mathrm{PE}=1 \mathrm{SV}=2\end{array}$ & 31 & 32 & 8 & 29.6 & 9.11 & 28 & 10.1 & -1.0 & -3.3 & -3.2 \\
\hline $28 b$ & P42055 & VDAC1_SOLTU & $\begin{array}{l}\text { Mitochondrial outer membrane protein porin of } 34 \\
\mathrm{kDa} \mathrm{OS}=\text { Solanum tuberosum } \mathrm{PE}=1 \mathrm{SV}=2\end{array}$ & 9 & 29 & 3 & 29.6 & 8.68 & & & & & \\
\hline $28 c$ & Q6K548 & VDAC1_ORYSJ & $\begin{array}{l}\text { Mitochondrial outer membrane protein porin } 1 \\
\mathrm{OS}=\text { Oryza sativa } \text { subsp. japonica } \mathrm{GN}=\mathrm{VDAC} 1 \\
\mathrm{PE}=1 \mathrm{SV}=3\end{array}$ & 4 & 26 & 1 & 29.2 & 7.07 & & & & & \\
\hline $28 d$ & P42056 & VDAC2_SOLTU & $\begin{array}{l}\text { Mitochondrial outer membrane protein porin of } \\
36 \mathrm{kDa} \mathrm{OS}=\text { Solanum tuberosum } \mathrm{PE}=1 \mathrm{SV}=2\end{array}$ & 4 & 27 & 1 & 29.4 & 7.78 & & & & & \\
\hline 29 & Q39434 & RB2BV_BETVU & $\begin{array}{l}\text { Ras-related protein Rab2BV OS = Beta vulgaris } \\
\mathrm{GN}=\mathrm{RAB} 2 \mathrm{BV} \mathrm{PE}=2 \mathrm{SV}=1\end{array}$ & 2 & 27 & 1 & 23.8 & 6.44 & 24 & 6.1 & 3.2 & -1.1 & -3.4 \\
\hline 30 & Q9SX33 & ALA9_ARATH & $\begin{array}{l}\text { Putative phospholipid-transporting ATPase } 9 \mathrm{OS}= \\
\text { Arabidopsis thaliana } \mathrm{GN}=\mathrm{ALA} 9 \mathrm{PE}=3 \mathrm{SV}=1\end{array}$ & 1 & 136 & 2 & 13.6 & 5.91 & 14 & 9.5 & -3.0 & 5.8 & 17.4 \\
\hline 31 & O48881 & TPS1_BRANA & $\begin{array}{l}\text { Thiamine biosynthetic bifunctional enzyme BTH1, } \\
\text { chloroplastic } \mathrm{OS}=\text { Brassica napus } \mathrm{GN}=\mathrm{BTH} 1 \\
\mathrm{PE}=1 \mathrm{SV}=1\end{array}$ & 2 & 59 & 1 & 56.0 & 7.15 & 21 & 5.5 & -1.8 & 1.7 & 3.1 \\
\hline $32 a$ & Q9SRT9 & RGP1_ARATH & $\begin{array}{l}\text { UDP-arabinopyranose mutase } 1 \mathrm{OS}=\text { Arabidopsis } \\
\text { thaliana } \mathrm{GN}=\mathrm{RGP} 1 \mathrm{PE}=1 \mathrm{SV}=1\end{array}$ & 26 & 39 & 6 & 40.6 & 5.61 & 38 & 6.2 & -1.3 & 7.1 & 9.5 \\
\hline $32 b$ & Q9LFW1 & RGP2_ARATH & $\begin{array}{l}\text { UDP-arabinopyranose mutase } 2 \mathrm{OS}=\text { Arabidopsis } \\
\text { thaliana } \mathrm{GN}=\mathrm{RGP} 2 \mathrm{PE}=1 \mathrm{SV}=1\end{array}$ & 12 & 40 & 4 & 40.9 & 5.76 & & & & & \\
\hline
\end{tabular}

Notes. Proteins in Figure 2 marked by arrows were analysed and identified by MALDI-TOF MS/MS. Some protein spots represented 2-7 different identified proteins. In the Table they are marked by $a-g$. An increase of spot intensity yields a positive fold-change and a decrease, accordingly a negative fold-change. ${ }^{1}-$ spot number, ${ }^{2}-$ accession number, ${ }^{3}-$ matching (sequence coverage, $\%$ ), ${ }^{4}$ - theoretical peptides, ${ }^{5}$ - digest peptides.

\section{Conclusion}

Comprehensive proteomic analysis of red clover cv. 'Vyčiai', berseem clover cv. 'Faraon' and white clover cv. 'Medūnai' was performed, more than 200 protein spots in each proteome map representing analysed clover pollen were visualised. Over 30 proteins were identified by using mass spectrometry analysis. Computer-assisted methods were adjusted for evaluation of increase/ decrease of the levels of these proteins in analyzed clover pollen protein maps. The identified proteins are involved in different cellular processes - structural and signalling proteins, proteins involved in metabolic processes, protein synthesis and folding, and others. To our knowledge, this proteomic study is the first comprehensive analysis of the protein profiles characteristic of pollen of red clover cv. 'Vyčiai', berseem clover cv. 'Faraon' and white clover cv. 'Medūnai'.

\section{Acknowledgements}

This research was funded by a grant (No. SVE-01/2012) from the Research Council of Lithuania. Postdoctoral fellowship (Dr. D. Matuzevičius) is being funded by European Union Structural Funds project "Postdoctoral Fellowship Implementation in Lithuania".

Received 09012014 Accepted 08072014

\section{References}

Badr A., El-Shazly, H. H., Watson L. E. 2008. Origin and ancestry of Egyptian clover (Trifolium alexandrinum L.) As revealed by AFLP markers. Genetic Resource and Crop Evolution. 55: 21-31 http://dx.doi.org/10.1007/s10722-007-9210-0

Bookstein F. L. 1989. Principal warps: thin plate splines and the decomposition of deformations. IEEE Transactions on Pattern Analysis Machine Intelligence, 11 (6): 567-585 http://dx.doi.org/10.1109/34.24792

Chen M., Thelen J. J. 2010. The plastid isoform of triose phosphate isomerase is required for the postgerminative transition from heterotrophic to autotrophic growth in Arabidopsis. The Plant Cell. 22 (1): 77-90 http://dx.doi.org/10.1105/tpc.109.071837

Croner L. J., Kaplan E. 1995. Receptive fields of P and M ganglion cells across the primate retina. Vision Research, 35 (1): 7-24 http://dx.doi.org/10.1016/0042-6989(94)E0066-T

Dai S., Li L., Chen T., Chong K., Xue Y., Wang T. 2006. Proteomic analysis of Oryza sativa mature pollen reveal novel proteins associated with pollen germination and tube growth. Proteomics. 6: 2504-2529 http://dx.doi.org/10.1002/pmic.200401351

Dowsey A. W., English J. A., Lisacek F., Morris J. S., Yang G. Z., Dunn M. J. 2010. Image analysis tools and emerging algorithms for expression proteomics. Proteomics. 10 (23): 4226-4257 http://dx.doi.org/10.1002/pmic.200900635

Ellison N. W., Liston A., Steiner J. J., Williams W. M., Taylor N. L. 2006. Molecular phylogenetics of the clover genus (Trifolium-Leguminosae). Molecular Phylogenetics and Evolution. 139: 688-705 http://dx.doi.org/10.1016/j.ympev.2006.01.004 
Filla J., Capkova V., Fecikova J., Honys D. 2011. Impact of homogenization and protein extraction conditions on the obtained tobacco pollen proteomic patterns. Biologia Plantarum. 55 (3): 499-506 http://dx.doi.org/10.1007/s10535-011-0116-5

Griftiths A. G., Barrett B. A., Simon D., Khan A. K., Bickerstaff P., Anderson C. B., Franzmayr B. K., Hancock K. R., Jones C. S. 2013. An integrated genetic linkage map for white clover (Trifolium repens L.) with alignment to Medicago. BMC Genomics, 14: 388-405 http://dx.doi.org/10.1186/1471-2164-14-388

Jevtic G., Andelkovic B., Lugic L., Nedic N., Matovic K. 2013. Colony strength in the spring inspection and its impact on the amount of foraged pollen at the time of red clover pollination. Biotechnology in Animal Husbandary, 29 (1): 115-122 http://dx.doi.org/10.2298/BAH1301115J

Kärkönen A., Murigneux A., Martinant J. P., Pepey E., Tatout C., Dudley B. J., Fry S. C. 2005. UDP-glucose dehydrogenases of maize: a role in cell wall pentose biosynthesis. Biochemical Journal, 391 (2): 409-415 http://dx.doi.org/10.1042/BJ20050800

Klinghammer M., Tenhaken R. 2007. Genome-wide analysis of the UDP-glucose dehydrogenase gene family in Arabidopsis, a key enzyme for matrix polysaccharides in cell walls. Journal of Exnerimental Botany, 58 (13): 3609 $3621 \mathrm{http}: / / \mathrm{dx}$.doi.org/10.1093/jxb/erm209

Lowe D. 2004. Distinctive image features from scale-invariant keypoints. International Journal of Computer Vision, 60 (2): $91-110$

http://dx.doi.org/10.1023/B:VISI.0000029664.99615.94

Matuzevicius D. 2010. Analysis of 2D electrophoresis gel images using intelligent techniques: doctoral thesis, Vilnius Gediminas Technical University. Vilnius, Lithuania

Matuzevicius D., Zurauskas E., Navakauskiene R., Navakauskas D.2008. Improved proteomic characterization of human myocardium and heart conduction system by comnutational methods. Biologiia. 54 (4): 283-289 http://dx.doi.org/10.2478/v10054-008-0058-9

Moller B., Posch S. 2009. Robust features for 2-DE gel image registration. Electronhoresis, 30: 4137-4148 http://dx.doi.org/10.1002/elps.200900293
Noir S., Brautigam A., Colby T., Schmidt J., Pastruga R. 2005. A reference map of the Arabidopsis thaliana mature pollen proteome. Biochemical and Biophysical Research Communications. 337: 1257-1266 http://dx.doi.org/10.1016/j.bbrc.2005.09.185

Serackis A., Navakauskas D. 2010. Treatment of over-saturated protein spots in two-dimensional electrophoresis gel images. Informatica, 21 (3): 409-424

Sheoran I. S., Ross A. R. S., Olson D. J. H., Sawhney V. K. 2007. Proteomic analysis of tomato (Lycopersicon esculentum) pollen. Journal of Experimental Botany. 58 (13): 35253535 http://dx.doi.org/10.1093/jxb/erm199

Sheoran I. S., Ross A. R., Olson D. J., Sawhney V. K. 2009. Differential expression of proteins in the wild type and 7B-1 male-sterile mutant anthers of tomato (Solanum lycopersicum): a proteomic analysis. Journal of Proteomics, 71 (6): 624-636 http://dx.doi.org/10.1016/j.jprot.2008.10.006

Shevchenko A., Wilm M., Vorm O., Mann M. 1996. Mass spectrometric sequencing of proteins silver-stained polvacrylamide gels. Analytical Chemistry, 68 (5): 850-858 http://dx.doi.org/10.1021/ac950914h

Vilčinskas E., Dabkevičienė G.2009. Qualitative and quantitative characteristics of clover (Trifolium spp.) species in the first year of growing. Zemdirbyste-Agriculture, 96 (4): 170 180 (in Lithuanian)

Vincent L., Soille P. 1991. Watersheds in digital spaces: an efficient algorithm based on immersion simulations. IEEE Transactions on Pattern Analysis Machine Intelligence, 13 (6): 583-598 http://dx.doi.org/10.1109/34.87344

Williams W. M., Nichols S. N. 2011. Trifolium. Kole Ch. (ed.). Wild crop relatives: genomic and breeding resources, legume crops and forages, p. 249-272

Wilson K. A., McManus M. T., Gordon M. E., Jordan T. W. 2002. The proteomics of senescence in leaves of white clover, Trifolium repens (L.). Proteomics, 2 (9): 1114-1122 http://dx.doi.org/10.1002/1615-9861(200209)2:9<1114::AIDPROT1114>3.0.CO;2-O

Zhu Y., Zhao P., Wu X., Wang W., Scali M., Cresti M. 2011. Proteomic identification of differentially expressed proteins in mature and germinated maize pollen. Acta Physiologica Plantarum. 33: 1467-1474 http://dx.doi.org/10.1007/s11738-010-0683-7

ISSN 1392-3196 / e-ISSN 2335-8947

Zemdirbyste-Agriculture, vol. 101, No. 4 (2014), p. 453-460

DOI $10.13080 / \mathrm{z}-\mathrm{a} .2014 .101 .058$

\title{
Raudonųjų, egiptinių ir baltụjų dobilų žiedadulkių lyginamoji proteominè analizè
}

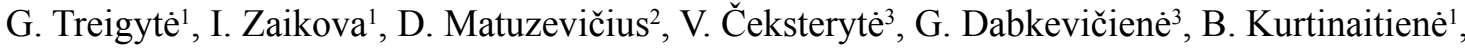 \\ R. Navakauskiené ${ }^{1}$ \\ ${ }^{1}$ Vilniaus universiteto Biochemijos institutas \\ ${ }^{2}$ Vilniaus Gedimino technikos universitetas \\ ${ }^{3}$ Lietuvos agrarinių ir miškų mokslų centro Žemdirbystès institutas
}

\section{Santrauka}

Dobilų, kaip ir daugelio kitų augalų, žiedadulkių proteomo (bendrojo baltymo) struktūriniai komponentai nèra visiškai ištyrinèti. Tyrimo metu atlikta proteomo išsami lyginamoji analizè skirtingų rūšių dobilų - raudonųjų, egiptinių ir baltuju - žiedadulkèse, surinktose rankomis. Baltymai, išskirti iš veislių 'Kiršiniai' bei 'Vyčiai' raudonųų, veislès 'Faraon' egiptinių ir veislès 'Medūnai' baltuju ų dobilų, populiacijų Nr. 2295 4n ir Nr. 2196 4n, buvo frakcionuoti elektroforetiškai pagal molekulinę masę. Nustatytos baltymų grupès, kurios pagal kiekybinį vaizdą skiriasi žiedadulkėse, surinktose iš skirtingų rūšių dobilų. Išsamiajai proteominei analizei pasirinktos veislès 'Vyčiai' raudonujų, veislès 'Faraon' egiptinių ir veislès 'Medūnai' baltujjų dobilų žiedadulkès. Baltymai, išskirti iš šių žiedadulkių, frakcionuoti dvimatẻje baltymų skirstymo sistemoje (2DE) ir vizualizuoti naudojant koloidinio Kumasi mėlio daža. Kiekviename iš gautu vaizdu identifikuota daugiau kaip 200 baltymų dėmelių. Taikant masių spektrometrinę analizę, identifikuota daugiau nei 30 baltymų. Pritaikius skaitinius metodus, buvo apibūdinti raudonujų, egiptinių ir baltųjų dobilų žiedadulkių baltymai. Šio tyrimo metu išplètoti skaitiniai metodai leido ịvertinti identifikuotų baltymų raiškos pakitimus raudonujų, egiptinių bei baltujų dobilų žiedadulkių proteomo žemèlapiuose, juos tiksliai apibūdinti nustatant molekulinę masę, izoelektrini tašką ir įvertinti kiekybinius pakitimus.

Reikšminiai žodžiai: proteominè analizè, Trifolium alexandrinum, T. pratense, T. repens, žiedadulkès. 